\title{
THE IMPROVEMENT OF STAFF PERFORMANCE THROUGH VARIATION OF LEADERSHIP APPROACH AT STATE VOCATIONAL HIGH SCHOOL (SMKN) 2 METRO ACADEMIC YEAR 2015/2016 BY \\ SUTARMAN (Principal of SMKN 2 Metro) Email:smkn2_metro@yahoo.com
}

Abstract :

SMKN 2 Metro, as one of vocational high schools potentially becomes a reference school, need to deal that possibility with high performace both teachers and staff. Reference school requires all staffs to manage and organize the school establishment in accordance with quality management procedure and do their best to improve their competency and qualification. The improvement of their competency and qualification is a supporting factor of the service provided by the school to all stake holders at SMKN 2 Metro. The aim of the research is to improve the performance of the staff at SMKN 2 Metro.It was school action research applied. This research was conducted to improve working situation and process to overcome problems of the school. SMKN 2 Metro is located at Street Yos Sudars, West Metro of Metro Municipal City. The subjcts of the research were staff consist of 13 civil servants (PNS) and 20 volunteer (PTT). It was done for three months from February to April 2015.The researcher was able to conclude that staff performance at SMKN 2 Metro improved when variation of leadership approach applied. This conclusion was supported by some findings. There was linear improvement of staff performance both PNS and PTT. The improvement of PTT performance was better than PNS in the beggining of the treatment, bu then they reached the same quality of improvement. Coersive power needed to be apllied more intensive in the beggining although applied with very careful manner. Flexible leadership approach must equip authoritative approach. Reward, even in smallest amount of recognition, must be applied more intensive.

Key Words: Approach, Performance, Staff

\section{A. Introduction}

One of the challenges which feels to be heaviest one for all school administrator is to prepare human resource to smart, high moral value, honest, skillful, and professional in science, technology, reliable management skill, and visionary by taking into account the past and present.As the implication, implementation of link and match of vocational education accentuates on education management must develop and improve to meet the construction and society demands, without neglecting religion norm, etchis morality, the great nation culture, both present and the future. At the level of SMK, setting and planning of school activities occurs due to interaction process of principal and staff. Needs to accomplish better instruction process can not be covered yet which means that not all the staff and teachers given a chance to improve their performance. Staff feels lack of recognition and become less involved in running the school. The staff performance of running the school can be executed both individual or group to smooth task 
implementation, behaviour control, work relation, problem solving, goal director or decision maker, etc. This strategic role can be carried out well when the staff always promote to grow their professional attitude and skill. It means that skill, trait, and professionality attitude, along with formal authority on the basis profficiency and tasks.

SMKN 2 Metro, as a vocational school potentially becomes a "Refference School (Sekolah Rujukan)", insist on high performance of the staffs and teachers to make it real. A reference school must establish school management with quality procedure and learn to continously improve their competency and skill. The improvement is one of crucial factors to establish best quality service to all stake holders of SMKN 2 Metro.

The fact shows that the average performance of staff, both civil servants (PNS) and volunteers (PTT) at SMKN 2 Metro, is still low. This statement taken after previous observation. The observation found that the average performance still at 56,61 (for PNS) and 54,87 (for PTT) from a scale 1-100. Normally, the average should rest on 70. Another problems need urgent solution were their lack of sense toward school achievement, lack of cooperative sense between team, lack of commitment to their duty and responsibility, lack of loyality to the institution, and lack of harmony.

The accomplishment of vision, mision, and goals of SMKN 2 Metro mostly depends on how the principal run the school. The principal ability to adapt his position through various approach of leadership will direct and affect staffs and teachers to do their best to fulfill the vision, mision, and goals. The research was aimed to describe the improvement of staffs'performance at SMKN 2 Metro.

\section{B.Research Method}

Action research, (Sagala, 2007:199)

is "Langkah-langkah tindakan (intervensi) yang dilakukan secara terencana dan sistematis untuk melakukan perbaikan dan peningkatan kualitas manajemen sekolah dan kualitas layanan belajar”. It is a School Action Research (known as PTS). PTS is directed effort to improve working atmosphere or working process to overcome performance problem met by the school. PTS is a reflective study by treatment subject to improve task execution, then to deepen the understanding of the treatments given. Hence, the activity improvement leads to working process betterment by the staffs or teachers. It cyclical steps. In case one cycle has not made better change, the treatment can continue to reach desired improvement. 


\section{Place, Subject, and Time of The}

Research

The research was done at SMKN 2

Metro, located at Street Yos Sudarso, Metro

Municipal City. Subjects of the research

were staffs, there were 33 members. As

many 13 out 33 were PNS, another 20 were

PTT. The research was carried out in three

months, from February to April 2015. It was done accordance with principalship task and duty.

\section{Duration of Treatment and Success}

Indicator

PTS is integrated into daily task of a principal as part of principalship. It is then adapted to routine schedule.

Table1. Duration and Success Indicator

\begin{tabular}{|c|c|c|c|}
\hline Duration & Performance Aspect & Success Indicator & Max \\
\hline \multirow[t]{9}{*}{2 weeks } & $\begin{array}{l}\text { 1) Relevancy of work } \\
\text { target }\end{array}$ & Minimum $70 \%$ achieved & $100 \%$ \\
\hline & $\begin{array}{l}\text { 2) Staff discipline toward } \\
\text { regulation }\end{array}$ & Minimum $80 \%$ achieved & $100 \%$ \\
\hline & 3) Time accuracy & 5 minutes late tolerance & Tepat \\
\hline & 4) Staff loyality & Never escape duty & Loyal \\
\hline & 5) Work quality & Minimum $80 \%$ achieved & $100 \%$ \\
\hline & $\begin{array}{l}\text { 6) Work Creativity of the } \\
\text { staffs }\end{array}$ & $\begin{array}{l}\text { Demonstrate certain technique } \\
\text { to accomplish task }\end{array}$ & $\begin{array}{l}\text { some } \\
\text { technique }\end{array}$ \\
\hline & 7) Works commitment; & Continual working & High \\
\hline & 8) Self esteem & Maintaing self esteem & High \\
\hline & 9) Works atmosphere & Harmony & $\begin{array}{l}\text { Dinamics } \\
\text { harmony }\end{array}$ \\
\hline
\end{tabular}

\section{Design of PTS}

\section{a. Planning}

First cyle was planned to

implement various leadership with

authoritative and trai approach.

Authoritative approach consist of unsures:

1) Legitimate power: subordinates do task due to given order by leader as authority, hereby subordinate must obey;2) Coersive power: subordinates do task due to effort to avoid punishment authorized to a leader; (3) Reward power: subordinates do task in order to get reward provided by the leader; (4) Referent power: subordinates do task due to their personal amazement to the leader, They feel amazed and need a leader's bless, and are willing to do what told to do, and (5) Expert power: subordinates do task due to their belief of special knowledge and skill mastered by the leader.

The implementation of trait approach because every leader has a trait combination, but the leader's trait must corelate to certain trait, activity, and goals of the followers. Based on trait approach, 
a leader'success is not only caused by personal traits but also his personal skill.

\section{b. Acting}

The implementation of authoritative approach done with the sequence:

1) Arranging special meeting with staffs with a formal invitation (a legitimate power)

2) Showing data of Staffs' low performance

3) Discussing job description of each staff and working mechanism;

4) Asking all staffs to improve their performance according to their job description;

The implementation of trait approach was followitng the sequence

1) Meeting staff personally and holding persuasive communication

2) Maintaining communication quality by presenting an attentive leader figure, expressing reward both verbal and nonverbal

\section{Result and Discussion}

1. Result

a. PNS Performance
3) Maintaning relation frequency. In this case, meeting frequency related to treatment and trait approach.

\section{c. Observation and Evaluation}

Observation done by the researcher himself. Observation focused on criterion aspects and accentuated on achieving process. The instrument used was checklist to measure performance indicators. Process observation was progress action obervation (right on time) when the staff under supervision doing his/her task.

\section{d. Analysis and Reflection}

Reflection related to observation result and evaluation done by principal with a person considered in charge with task success. This person can be the head of staffs. Together reflection was done to confirm data accuracy as part of data triangulation. What obtained after the reflection suggest what treatment should apply next

Data related to performance indicators can be seen on the pictures below. 


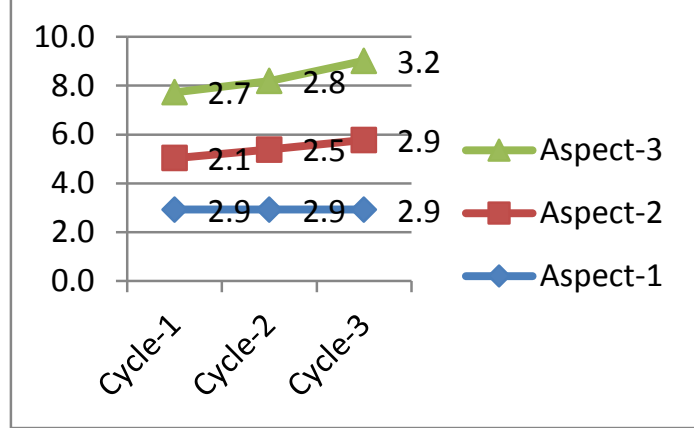

Picture 1. The Average of PNS Aspect Indicators

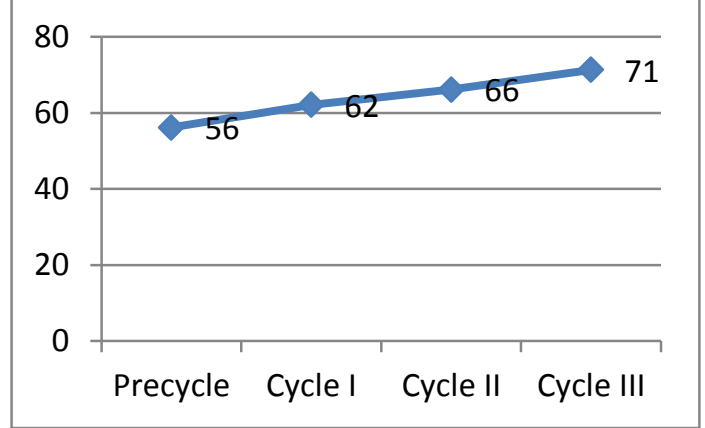

Picture 2. The Average of PNS Performance
Indicator aspects are 1) quality; 2) quantity; and 3) impact. Based on average score of all aspects done by PNS, with 1-4 scale, the distribution were: quality aspek 2,92 , quantity aspect 2,12 , and impact aspect 2,69. Quality aspect reached the highest score in cycle I. At cycle II, quality aspek 2,92, quantity aspect 2,46, and impact aspect 3,24. At cycle III, quality aspek 2,92 , quantity aspect 2,86 , and impact aspect 3,24.The evaluation of PNS performance was based on average calculation from all staffs with all aspect indicators. The average was percentage. Before treatment, PNS average was $56,61 \%$, it reached $62,21 \%$ at cycle I, reached 66,15 at cycle II, and reached 71,35 at cycle III

\section{PTT Performance}

Data related to PTTs performance can be seen on the picture belows

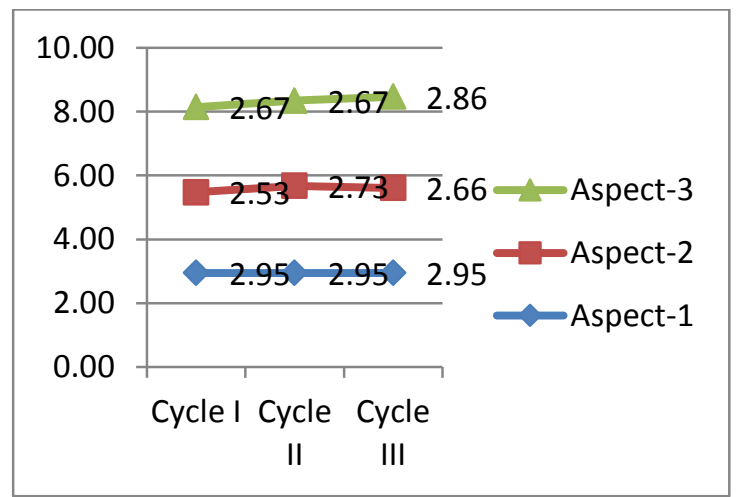

Picture 3. Aspect Average of Indicator PTTs

Based on average score of all aspects done by PTT, with 1-4 scale, the distribution were: quality aspek 2,95, quantity aspect 2,53 , and impact aspect

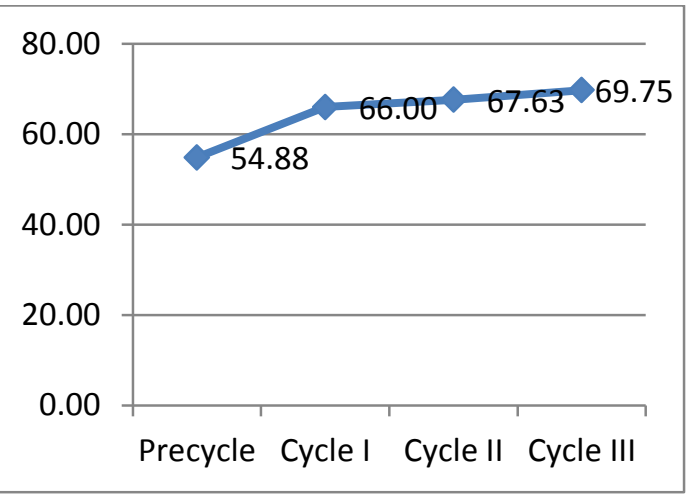

Picture 4. Improvement of Performance PTTs

2,67. Quality aspect reached the highest score in cycle I. At cycle II, quality aspek 2,92 , quantity aspect 2,73 , and impact aspect 2,67. It was heavier to improve 
impact score because the aspect has to do with outcome from all staffs. Outcome factor depend on how the person embrace value system as a phyloshopy of life. When a staff embrace higher value system, he/she will likely to act consistently on task finishing. At cycle III, quality aspek 2,92, quantity aspect 2,66, and impact aspect 2,92.

\section{B. Discussion}

\section{Aspect of Performance Indicator}

Every individual has different character. Even so, the motives lay behind what people do usually the same in general. At point, a principal as a leader must see things properly, what motif most suited to a staff as an individual. When a motif of a staff identifed correctly, it will be much easier for a leader to direct his/her behaviour to reach education organization goals.

Every basic needs required by an individual is actually the same. What differs is the level of the needs. When a basic needs is already achieved, a person tends to decrease his performance from his losing interest of running after the basic needs. In the contrary, to a person whom his basic needs is achieved yet, he will likely demonstrate persistency to reach the needs. The logic analysis behind this situation is when a person with an
The evaluation of PTT performance was based on average calculation from all staffs with all aspect indicators. The average was percentage. Before treatment, PTT average was $54,875 \%$, it reached $66,00 \%$ at cycle I, reached 67,63 at cycle II, and reached 69,75 at cycle III.

achieved basic needs expected to demonstrate his high performance, the person must be made in a situation where he constantly need other higher needs.

Mostly for PNSs, their main needs already achieved. The condition tends to provoke them to neglect their responsibility and henceby their work fail to meet requirements. This phenomena rose early in the first cycle. When treatment by principal managed to shift their needs, from worldly needs to heavenly needs, they slowly changed their behaviour. Recognition of their performance, skill, and accentuation on religious value as a form of self actualisation has improved their performance. The awareness that it is not physical needs only to fulfill but self actualisation is to motivate more.

For PTTs, their main needs is their life needs, which is why they try to hold on their job to meet the needs and make a 
living. It made sense when they try to maintain their performance indicator to a sufficient level. Basic needs factor drive people to survive, when their survival instinct equipped with sufficient understanding about goal and life meaning, they will exert persistency to reach better life level. This is a point where a principal as a leader and boss transfers the understanding of purpose and life meaning for younger PTTs, and share his experience to older PTTs.

When situational approach was applied, principal treatment gave a personal impression to both PNSs and PTTs. Apart from some misunderstanding sometimes occured when the principal deliver the treatment, especially related to organization goals, the principal had show open minded and adressed apology to all. The effort of improvement also attracted other school community member, the teachers. Teachers as part of school unit delivered positive evaluation and impression which eventually effected the process of understanding to PTTs. Interaction between staffs and teachers became a good media to transfer the understanding of life meaning and purpose.

\section{Performance Average}

Accumulatively, performance average of PNSs and PTTs can be seen on the picture below

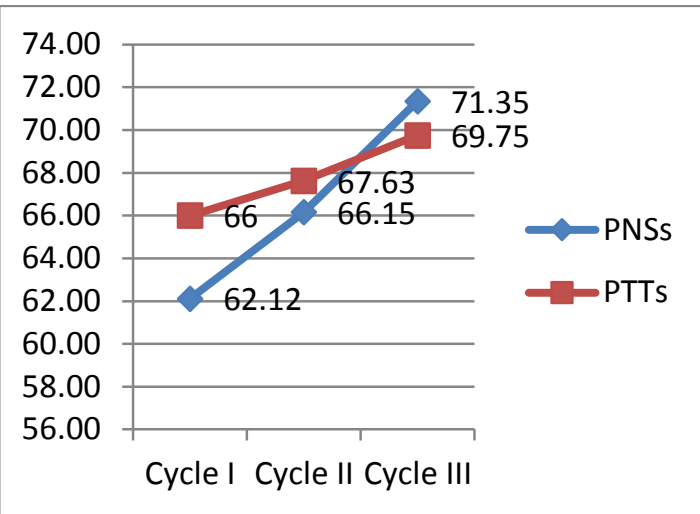

Picture 5. Performance Average of PNSs and PTTs from All Cycles

The picture above clearly explain the improvement of performance linearly both PNSs and PTTs. PNSs Performance increased 4,04 point from cycle I to cycle II, increased 5,19 point from cycle II to cycle III. Total amount of increase was 9,23 point. PTTs performance increased 1,63 point from cycle I to cycle II, increased 2,13 point from cycle II to cycle III. Total amount of increase was 3,75 point. In the beggining, PTTs reached higher performance average than PNS did, but later, PNSs Performace reached higher than PTTs did.

Statistically speaking, the difference of performance average in cycle III between PNSs and PTTs can be ignored. What made it interesting was that the phenomena as the effect of the approach applied. The leadership 
approach applied in cycle III was

situational approach. Authoritative unsure applied was reward. Reward applied was more like recognition and more humanly treatment. The humanly treatment were respect and trust. Respect adressed to all staffs made them deeply touched. This condition went along with what Douglas (2009:5) stated, "Apart from anything you do as a Boss, whether they are hiring, training, policy reviewing, or other activities, what you must do is to ask yourself a question,'have I treated my employee with respect and trust?"'. Treat the staffs with respect and trust is effective medicine to improve their performance.

Trust is to adress recognition on the performance of staffs, a chance for them to develop and apply all resources inside them to accomplish task of their main function. Recognition of performance in any kind, range from compliment to reward which is not significant compared to amount of money, stabilize their psyclogy to work. Douglas (2009,p.82) clearly stated that:

"Adressing thanks, point credit, and compliment to your employee when you gained a beneficial from their performance, is a proper, easy, and cheap method to keep improving behaviour, moral, self esteem, self confident, loyality, and even their productivity. Most of employee todays are really enjoying positive feedback from their leader, and generally, they will feel deep disappointment when they lost the positive feedback they deserved.

In accordance with above statement, Danim and Suparno (2009:81) stated that" Memberikan reward atau penghargaan sangat penting untuk meningkatkan kegiatan yang produktif dan mengurangi kegiatan yang kontraproduktif".

Respect and trust are proven to be effective to shift from physical needs to self actualisation needs. The existence of openness and financial transparency at every activity and program were the form of trust from a principal to staffs. No matter how much incentive they got, as part of physical needs, they will maintain their highest performance. The effort of improving the performance is one of ways to payback from a subordinate to a Boss or a leader. The implementation of cause and effect laws. This is in accordance to what Nawawi (1997,p.81) said that

"Kepemimpinan sebagai kemampuan menggerakkan, memberikan motivasi, dan mempengaruhi orang-orang agar bersedia melakukan tindakantindakan yang terarah pada pencapaian tujuan melalui keberanian mengambil keputusan tentang kegiatan yang harus dilakukan. Dalam suatu organisasi belajar pemimpin memiliki peran: 1) sebagai pendesain; 2) sebagai penolong; 3$)$ sebagai guru". 
Slight difference of performance average between PNSs and PTTs at the end of cycle III, is understandable, because a tolerance toward physical needs due their lower payment. The most important thing was that all staffs, both PNSs and PTTs have demonstrated good performance. It is true that principal orchestrate school atmospehere as it is said, "Principal is those who know their assignments and rythim for their school (Lipham, 1985,p.1).

\section{Closing}

\section{Conclusion}

It could be concluded that performance of staffs of SMKN 2 Metro improved from the implementation of leadership variation approach. To support this conclusion were the improvement of performance average linearly, both PNSs and PPTs. PNSs performance from cycle I to II increased 4,04 point, from cycle II to cycle III increased 5,19 point, and the total amount of improvement is 9,23 point. PTTs performance from cycle I to II increased 1,63 point, from cycle II to cycle III increased 2,13 point, and the total amount of improvement is 3,75 point. In the beggining, PTTs performance is higher than PTTs but finally PNSs performance was higher than PTTs.

\section{B. Suggestion}

Suggestions are as follows:

1) Authoritative approach must become the basic of various approaach implementation

2) Trait must be considered when approach implemented. More intensive implementation of coersive power, subtle punishment such as verbal warning to improve staffs performance. Principal must demonstrate humanly treatment, when necessary, the principal must involve technically to many kind of problem solution. The steps of how to do it covers; 1) clarify task and function of all personal; 2) provide insight individually; 3 ) individual surveilence through crosschecking; 5) improving discpline persuasively by having a talk face to face; 6) decision with clarification

3) The implementation of situational approach integrated with authoritative approch. This approach allows the principal to understand how prepared each staff. More intensification on reward both verbal and nonverbal. Another thing to add, reward is a celebration from achieved performance. 


\section{Reference}

Danim, Sudarwan dan Suparno. 2009.

Manajemen dan Kepemimpinan

Transfor-masional

Kekepalasekolahan. PT. Rineka

Cipta: Jakarta

Douglas Jr., Kevin. 2009. How to Be a Perfect Boss. Terjemahan. Prestasi Pustaka Publisher. Jakarta
Lipham, James M. 1985. The Principal

Concepts, Competencies, and Cases. Longman Inc: New York. Nawawi, Hadari. 1997. Manajemen Sumber Daya Manusia Untuk Bisnis yang Kompetitif. Gajah Mada University Press: Yogyakarta

Sagala, Syaiful. 2007. Manajemen Stratejik dalam Peningkatan Mutu Pendidikan. Alfabeta. Bandung. 